\title{
RECENT DEVELOPMENTS IN THE APPLICATION OF THE FOREIGN INVESTMENT REVIEW ACT TO THE OIL INDUSTRY
}

\author{
K. B. POTTER*
}

\begin{abstract}
The author reviews recent developments relating to the Foreign Investment Review Act, in particular, the introduction of guidelines with respect to acquisitions of interests in oil and gas rights and Part II of the Act dealing with the establishment of new businesses. He discusses the basis of reviewability under the Act, how various transactions and activities are classified under the guidelines, and problems and deficiencies arising out of the resulting classification. He outlines the guidelines issued by the Agency that deal with the question of whether two businesses are related and comments on problems and implications arising from undertakings extracted by the Agency from applicants seeking approval of acquisitions. The writer views the most significant effect of the Act as encouraging companies to Canadianize and thereby comply with the Act by avoiding it. He accordingly reviews some possible ways to Canadianize. Finally, he outlines title problems created by the Act and counsel's duties regarding the applicability of the Act to the purchase and sale of a Canadian Business Enterprise.
\end{abstract}

\section{INTRODUCTION}

In February, 1975, a seminar was held at the Mid-Winter Meeting of the Canadian Petroleum Law Foundation dealing with the effect of the Foreign Investment Review Act ${ }^{1}$ on the oil and gas industry. At that time the industry was very concerned about the applications of the Act. Such concern was primarily the result of informal opinions or advice given, or purported to have been given by the Foreign Investment Review Agency ${ }^{2}$ to some oil companies and their counsel to the effect that farmout agreements involving land on which any exploration work had been done by anyone was considered by the Agency to be a reviewable transaction if its value exceeded the small business exemption. ${ }^{3}$ The Senior Legal Advisor to the Agency at the time, Mr. William Rosenfeld, was a panelist and did much to dispel the erroneous views previously expressed or rumored to have been expressed by the Agency.

In the one and one-half years which have since elapsed, there have been many developments relating to the Act but two have stood out as being of prime importance to the oil industry. The first is the introduction of guidelines with respect to acquisitions of interests in oil and gas rights, and the second is the proclamation of Part II of the Act dealing with the establishment of new businesses. This paper will review such developments and will comment on other topics such as: (1) dealing with the Agency, (2) Canadianization, (3) counsel's duty on a sale or purchase, and (4) title problems arising as a result of the Act. In view of the now fairly substantial volume of literature ${ }^{4}$ dealing with the basic provisions of the Act and in particular Part I, there will be no discussion of such provisions.

\footnotetext{
- Barrister and Solicitor, Macleod Dixon, Calgary, Alberta.

1. S.C. 1973 , c. 46 , hereinafter sometimes called the "Act".

2. Hereinafter called the "Agency".

3. The $\$ 250,000$ asseto- $\$ 3,000,000$ gross revenue exemption contained in $8.5(1)$ (c) of the Act.

4. See the list annexed of materials and articles on the Act (Appendix I). This list is an updated version of a list included in materials supplied by the Federation of Law Societies of Canada for a seminar held in Banff in Sept., 1975.
} 
Prior to May 1976, approximately 439 applications for approvals of acquisitions were filed with the Agency. Of these 19 have been withdrawn, 84 returned as non-reviewable, 27 are awaiting certification pending receipt of information, and 309 have been certified as reviewable. Of the 309 certified reviewable applications, 257 have been resolved with 182 approvals, 37 disallowances and 38 withdrawals. As of May 1976, 52 applications were in the assessment stage. Only 25 applications have involved the oil industry (which includes oil service industries) and of these 19 have been allowed, 3 withdrawn, 1 disallowed and 2 are in progress. The overall average time for Part I applications which were approved is 116 days from the date of certification (that is the date on which all information required or demanded by the Agency is supplied which normally comes within three to four weeks after receipt of the application by the Agency). The average time for the oil related approvals has been 117 days.

Prior to May 1976, 49 applications for approvals for the establishment of new businesses were filed and certified. Of these, 12 were resolved with 9 approvals and 3 withdrawals. The remaining 37 were under review. None of these applications were oil related.

During the same period, a total of 54 applications for section 4(1) rulings with respect to eligibility were filed (13 of which were oil related). Twenty-eight of these applications have been resolved favourably (9 oil related) and 14 withdrawn. Fourteen applications are in progress (4 oil related) and no unfavourable rulings have been given. ${ }^{5}$ No statistics are kept on the time to obtain a ruling, but the Agency advises it takes longer generally than a Part I application.

\section{OIL AND GAS GUIDELINES}

At the 1975 Mid-Winter Meeting one panelist, Mr. Peter Hayden, strongly advocated the introduction of oil and gas guidelines. Another speaker, Mr. Les Duncan, felt them to be unnecessary and was apprehensive of the industry's request for guidelines. For better or for worse, depending on one's point of view, oil and gas guidelines ${ }^{6}$ were introduced in February, 1976. They were drafted by an ad hoc committee consisting of representatives of the Agency and legal representatives of the Canadian Petroleum Association. The guidelines primarily deal with problems of determining when oil and gas properties constitute a business, the acquisition of which is subject to review under the Act. These guidelines are, probably out of necessity, drafted in terms of concepts rather than detailed, rigid rules. As shall be discussed, the guidelines, while solving a number of problems, leave a number of others unresolved.

The difficult task facing the committee was to find a formula which would be workable from an industry point of view while at the same time preventing acquisitions of all the assets of a company to be made without being subject to review. The guidelines differentiate between the exploration phase and the production phase of oil and gas operations; transactions involving exploratory properties are generally non-

5. This is undoubtedly a result of applicants anticipating an unfavourable ruling withdrawing their application rather than receiving a negative response.

6. These guidelines are sometimes in this part referred to as the "guidelines". They were introduced under the authority of 8 . $4(2)$ of the Act, but it should be cautioned that they serve as a guide to administration of the Act and do not have the force of law. 
reviewable while transactions involving producing properties may be reviewable.

\section{Non-Reviewable Transactions}

A numbr of activities and transactions are expressly excluded from review by the guidelines. These include:

(a) the acquisition of permits, leases, reservations, and similar rights from the Crown or freehold owners for exploration purposes;

(b) normal farmout agreements of exploratory property before or during the exploration phase; 7

(c) the purchase or assignment of interests in exploration properties; ${ }^{7 a}$

(d) joint operating, pooling or unitization arrangements involving producing or non-producing properties, including changes in percentage interests due to work commitments or defaults.

\section{Possibly Reviewable Transactions}

Farmouts, sales, or assignments of all or substantially all of the property of a company may be reviewable unless the vendor is a lease broker, in which case it is reviewable only if it is a step in the windingup of the business. A property which is at the production stage will ordinarily be presumed to be a business if it can reasonably be expected to sustain a separate business by reason, for example, of the existence of proven reserves. The guidelines do, however, recognize that some production can occur during the exploration phase without altering the exploratory nature of the activities.

The problem with such a delineation of the activities of the industry is that it is not always easy to determine when one is in the exploratory phase and when one is in the production phase. For example, if a small company makes a discovery and drills a few delineation wells but does not have the funds to fully develop the property, it is necessary for them to either sell the property or farmout the acreage. The question then arises as to whether such a sale or farmout would be considered a transaction involving exploratory or producing properties. This writer's experience has been that the Agency will treat it as a non-reviewable transaction provided the property has not been on production, and there is no ulterior purpose to it not having gone on production. However, as a result of the uncertainty with respect to where the dividing lines lie, it may be desirable to apply to the Agency for a no-action letter with respect to the transaction. ${ }^{8}$ The Agency has, in this writer's experience, been very helpful in considering such requests promptly.

A second problem which arises out of the delineation is determining when a property which is at the production stage can be reasonably expected to sustain a separate business; for only if it can be so considered is the acquisition reviewable. The Act provides ${ }^{9}$ that an acquisition of a business, the gross assets of which exceed $\$ 250,000$, or the gross revenue of which is in excess of $\$ 3,000,000$, is reviewable. This test, however, presumes that what has been acquired is a business and it is submitted that in an oil context the question remains as to whether a property

7. These are both subject to the limitation that if the property is all or substantially all of the oil and gas rights of the vendor, there could be an acquisition of a business except in the case of lease brokers.

7a.Id.

8. This is a procedure the Agency has adopted for giving advice on whether transactions are reviewable. It has no statutory basis and the letter you receive makes it clear that the letter is not binding on the Minister.

9. S. $5 \times 1)(c)$. 
which has a value of $\$ 250,000$ is considered as a business. It would seem that the answer to this depends on whether the property can reasonably be expected to sustain a separate business. It would be doubtful that a property worth $\$ 250,000$ could reasonably be expected to sustain a separate business on any objective sort of basis as the annual cash flow from such property would not be very substantial. If this interpretation is correct the $\$ 250,000$ asset to $\$ 3,000,000$ revenue test contained in the Act is not of much relevance in an oil context. Presumably a property can be said to sustain a separate business when it has sufficient revenue to retire indebtedness incurred to develop the property and bear a certain modest overhead. An objective test must obviously be applied. The problem is that the views of the industry or their counsel and the Agency may well differ. This will require some soul searching in drafting opinion and no-action letters may be called for in some situations.

\section{Transactions Not Covered by the Guidelines}

The guidelines do not deal with the question of how non-working interests such as royalties or net profits interests shoud be treated. At the mid-winter meeting in 1975 the Senior Legal Advisor to the Agency indicated that acquisitions of such interests would not be considered as the acquisition of a business. The writer has had occasion to recently discuss this problem with the Agency, and the indication received was that they would probably not consider an acquisition of a net profit interest as a business. However, their views cannot be taken as covering all fact situations because their opinion could depend on such factors as the size of the royalty and the rights given to the royalty owner. Their reaction of non-reviewability was prefaced on the understanding that the interest in question was a passive type interest in which the owner of the interest had no control whatsoever over the property.

The guidelines seem to suggest that the acquisition of an interest in a non-producing bituminous sands lease would not be reviewable as it could not be said to support a separate business, unless one considers the reserves as proven. In view of the fact that no one can finance on the basis of such reserves at present, the writer does not feel there should be much question in this area. However, Hudson's Bay Oil \& Gas Company Ltd. and Pacific Petroleums Ltd. applied for and obtained approval with respect to their acquisitions of Candel's interests in bituminous sands leases, and Japanese interests recently obtained approval from the Agency to their acquisition of an interest in Norcen's heavy oil project at Cold Lake. It is understood that in the HBOG case, the approval of the Agency was obtained more as a precaution than as a necessity. The Japanese approval may have been obtained as a result of Part II of the Act.

The guidelines fail to clarify the application of the Act to the sale of non-Canadian assets of a Canadian business enterprise. One would expect that the Act, being a Canadian Act concerned with control of Canadian property, should not apply to dispositions by a Canadian company of foreign assets. However, as a result of sections $3(6)(f)$ and 3(6)(g) of the Act, an argument can be raised that such a disposition would be a reviewable transaction. Section $3(6)(\mathrm{f})$ provides that a Canadian business shall be deemed to be carried on in Canada, 
notwithstanding that it is carried on partly in Canada and partly in some other place. Section $3(6)(\mathrm{g})$ then goes on to provide that a part of a business that is capable of being carried on as a separate business is a Canadian business enterprise if the business of which it is a part is a Canadian business enterprise. This would mean that if, for example, a Canadian incorporated oil company has substantial producing property in the United States which could be carried on as a separate business and it disposes of that property, then because it is part of a Canadian business enterprise, it is deemed to be a Canadian business enterprise and thus a disposition subject to review. The writer doubts whether the Agency would question the sale of non-Canadian assets, ${ }^{10}$ but the potential is there and the question has been raised for consideration in a number of transactions of which the writer is aware. It would have been helpful if the guidelines resolved this issue. A related question arises in respect of recently consummated transactions involving Sunningdale Oils Ltd. The Canadian assets were being sold by Sunningdale and then a successful take-over bid was made by Kerr McGee. An interesting question arises as to whether Sunningdale is still a Canadian business enterprise after the Canadian assets are sold.11

A further area which the writer had hoped the guidelines would deal with is the applicability of the Act to rights of first refusal which are common place in the industry. Consider for example the situation where a right of first refusal is granted on exploratory acreage but exercised at a time when the property is a valuable producing property. In the writer's view the acquisition of the right is, a contingent right to acquire the property under 3(6)(c) of the Act, deemed to be the acquisition of the property and if it is exploratory property when the right is acquired it is not reviewable. Section 3(6)(d.1) deems the exercise not to be an acquisition of the property and thus even if it is producing at the time of exercise of the right it is still not reviewable. The Agency however does not agree that a right of first refusal is within section $3(6)(c) .^{11^{a}}$ If the exercise is reviewable it will destroy the effectiveness of such rights as the writer has never seen one which allowed 117 days to exercise it.

\section{PHASE II OF THE ACT}

Prior to October 15,1975, anyone could, without applying to the Agency, establish any new business in Canada or take over any existing business if its assets were less than $\$ 250,000$, and its revenues were less than $\$ 3,000,000$. Effective October 15,1975 Phase $I^{12}$ of the Act came into force and as a result the following transactions which were previously not reviewable became reviewable:

(a) the establishment of any new business by a non-eligible person, ${ }^{13}$ or a group any member of which is a NEP who did not carry on business in Canada before October 15, 1975;

10. The Agency may have a basis for concern in situations where the disposition may have an effect on foreign exports.

11. The Act defines a Canadian business in part as a business carried on in Canada by a corporation incorporated in Canada. If the old taxation test of where central management and control is located is where the company resides applies, then if management resides in Canada the business would still be carried on in Canada. It is doubtful, however, that this is an appropriate test.

11a The Agency takes the position that a right of first refusal is not a contingent right to acquire. The views of the Supreme Court of Canada in Canadian Long Island Petroleums Ltd. v. Irving Industries Ltd. (1975) 50 D.L.R. (3d) 265 may lend support to its argument.

12. See sections 6, 8(2) and $31(2)$ of the Act.

13. Hereinafter, sometimes called a "NEP". 
(b) the acquisition of control of any Canadian business enterprise by a NEP, or a group any member of which is a NEP, who was not in business in Canada before October 15, 1975;

(c) the establishment of a new business in Canada (which includes the expansion of an existing business into an unrelated area) by a NEP or a group any member of which is a NEP, who previously was in business in Canada, if such new business is unrelated to the existing business;

(d) the acquisition of control by a NEP, or a group any member of which is a NEP, who was previously in business in Canada, of any Canadian business enterprise ${ }^{14}$ that is unrelated to the existing business of such person or group of persons.

One particular aspect of the foregoing which should be noted is that the new business provisions apply where any member of a group is a NEP, regardless of his interest in, or influence on, the business. There is no saving provision similar to that for group control of corporations. ${ }^{15} \mathrm{At}$ the time of the announcement of the proclamation of Phase II the Related Business Guidelines were introduced to deal with the questions of when a business is a new business and when a new business is related to an existing business. These guidelines will be discussed subsequently.

\section{Meaning of New Business}

A new business is defined ${ }^{16}$ as a business ${ }^{17}$ not previously carried on in Canada by the person or group of persons in relation to which the expression is used. The related business guidelines indicate that in determining whether a business is a new business the principal factor is the character of the goods and services produced by the new activity. If the goods or services are substantially similar to those of the established business, a new business has not been established.

As a result of this definition of "new business" and the wording of Section 8(2), it is arguable that the group establishing the business must, as a group, have carried on that business in Canada previously, and if they did not so carry on business, any business which the group establishes would be a new business and thus subject to review, even though all the members of the group had previously carried on the same business in their own right or as members of other groups. Although this is arguable the writer understands that the Agency is not advocating it, at least insofar as the oil industry is concerned, and provided all of the members of the group have previously carried on that same type of business, albeit not all together, there is no problem. This is consistent with the approach of the Agency that companies involved in the oil industry who enter into a joint venture or act as a group are each considered as carrying on their own individual business as a member of the group, and the joint venture property is not considered as one business but rather as a number of businesses.

\section{When is a Business Established?}

One of the key words in Section 8(2) (being the operative section

14. Including those with assets of less than $\$ 250,000$ and revenues of less than $\$ 3,000,000$. They continue to enjoy the benefit of the small business exception for related businesses.

15. S. 3(6)(b.1) of the Act.

16. S. 3(1) of the Act.

17. Which is in turn defined very broadly as including any undertaking or enterprise carried on in anticipation of profit. 
relative to Phase II) is "establish". Section 3(4) of the Act is useful in determining when a business is considered to be established. This section provides that a business is established only if there is an establishment in Canada to which one or more employees of the person or group of persons establishing the business report for work in connection with the business, and the time at which a business is established is the time at which the first of such employees reports for work in connection with the business at such an establishment.

The key elements required by this section are an establishment and employees who report to work at the establishment. If either of these elements is missing, it is suggested that a business is not established for purposes of the Act.

What the word "establishment" means is somewhat questionable, although perhaps one can obtain assistance from the definition of "permanent establishment" in the tax treaties. From the context of the section it is submitted that the word "establishment" means premises or physical facilities, and if there are no premises or physical facilities in which the business has some interest, it cannot be said that there is an establishment. The question which arises in an oil and gas context, is whether an oil and gas well or an interest therein would be considered as an establishment. It would certainly be so considered for the purpose of the tax treaties but this is as a result of specific words. The writer has not discussed this specifically with the Agency, but would anticipate that they would take the point of view that such would qualify as an establishment for purposes of the Act.

Because of the requirement for employees it is possible to suggest that a sole individual proprietor without employees could operate in Canada without Agency approval. It has been the writer's experience that the Agency is taking a very liberal view of the meaning of "employee" and would consider, for example, that employees of the operator of a property would be deemed employees of a non-operator if that non-operator has none of his own. Since section 3(4) specifically refers to "employees of the person or group of persons establishing the business", it is submitted that the Agency's view is not legally tenable particularly in view of the well-defined legal connotation of the word "employee". The real estate guidelines deal with the concept of employees and, consistent with the views taken by the Agency in an oil context, play down the importance of employees. The real estate guidelines in Part IV state that "Whether employees report for work is not an essential factor in determining whether an activity is a business. Therefore, an activity involving real estate may be a business even if no employees are employed on or in connection with the real estate." Although the Agency's position may not be sustainable legally, few people can afford the luxury of time or expense involved in a formal challenge.

It has been suggested ${ }^{18}$ that section $3(6)(\mathrm{h})$ of the Act may have an effect on the concept of a new business. In a situation where a foreign company controls a Canadian business enterprise, then by virtue of $3(6)(\mathrm{h})$ the parent is deemed to be carrying on the business conducted by the Canadian business enterprise and is thus considered as being in that business in Canada. Accordingly, the parent's subsequent direct 
involvement in such a business or a related business would not be reviewable.

The broad wording of the Act would indicate that any business carried on by a new subsidiary would be a reviewable transaction on the basis that the new company will never have previously carried on any business. The notes to section 3 of the Related Business Guidelines indicate that the Agency will not take this view and will permit established businesses to use new organizational arrangements. A related, but more difficult problem arises where a NEP has, for example, a $50 \%$ shareholding interest in a company doing business in Canada. Is this sufficient to consider him as being in business so that he personally could form new companies in a related area without review?

\section{Application of New Business Provisions to Drilling Funds}

One interesting practical application of the new business provisions is to drilling funds (which generally are limited partnerships) which operate in Canada. Typically the general partner is a company which has been operating in Canada prior to the proclamation of Phase II. Each year one or more new drilling funds are formed and the limited partners change from drilling fund to drilling fund, although there is often a carry-over of limited partners. As a result of the fact that the limited partners vary from year to year, it is arguable that each new drilling fund would be a separate business carried on by a group of persons which did not previously carry on business in Canada and if the group includes a non-eligible person, approval would have to be obtained in order for it to operate in Canada. Often these drilling funds are formed at or near a fiscal year-end and as such, the timing does not allow for protracted negotiations with the Agency in order to determine whether they should be permitted to undertake activities in Canada. It is arguable that because of the requirement of section $3(4)$ that there be "employees of the person or group of persons establishing the business", a limited partnership would not require approval as it would never have employees of its own. This is somewhat tenuous, and is admittedly on the slight side to be relied upon for opinion purposes. At a seminar held in September, 1975 in Banff, the Senior Legal Advisors to the Agency indicated that the Agency was considering the view that in a situation where a group of investors do nothing more than supply money, and have no input or right to acquire or exercise any control over the operation of the business (which is the case of limited partners in a limited partnership) the Agency would not consider such persons as being a member of a group of persons establishing a business. In other words they would ignore the limited partners and look only to the general partner, and if it has previously been in business in Canada, no approval would be required. The Agency has issued a no-action letter which permits non-eligible persons who had, prior to October 15, 1975, carried on such funds to continue to form new funds without approval.

It is not uncommon for limited partnership agreements to provide a guaranteed buy-back by the general partner of either the partnership interests or the underlying assets after a certain number of years have expired. This raises interesting questions as to whether, at such a time, the acquisition by the general partner of either units in the partnership from the limited partners, or the acquisition of the limited partners' beneficial interest in the property of the partnership, would be a reviewable transaction. As a limited partner's interest in a limited 
partnership is neither shares nor property used in carrying on a business within section $3(3)$ (a)(iii) the acquisition of such would not seem to be reviewable. The acquisition of underlying property from limited partners or the beneficial interest in such property is a more difficult transaction to categorize and more likely to be reviewable.

\section{Related Business Guidelines}

The Agency has issued related business guidelines designed to help deal with the question of when the establishment of a new business, or the expansion of an existing one, or the acquisition of a small one, is related to an existing business. If the guidelines do not provide a clear answer or if the answer provided by the guidelines does not seem appropriate it is possible to apply under section 4(1) of the Act for an opinion of the Minister on the question of whether the business is related.

In reviewing the guidelines it is proposed to interpret them against the following hypothetical situations which could likely arise in an oil and gas context:

(a) An oil and gas producing company wishes to establish a chemicals plant, using as feedstock for the chemical plant oil or gas produced from the company's lands.

(b) A company involved strictly in an oilfield service business wishes to go into oil and gas exploration.

(c) An oil and gas company wishes to construct a gas plant to process its gas and/or gas of other operators.

(d) An oil and gas producer wishes to become involved in a synthetic crude project. ${ }^{19}$

(e) An oil and gas company wishes to become involved in exploration for and production of minerals or coal.

The guidelines outline a number of factors to be considered in answering the question of when businesses are related. If any one of the six guidelines are satisfied the businesses are considered to be related. A new business ${ }^{20}$ is related to an established business if the new business:

(a) is vertically integrated with the existing business (guidelines 1 and 2);

(b) produces products or services directly substitutable for existing products (guideline 3);

(c) uses the same technology and production processes as the existing business (guideline 4);

(d) results from research and development carried on behalf of the existing business (guideline 5); and

(e) is in the same industrial classification as the existing business (guideline 6).

It is proposed to review briefly each of these guidelines.

(a) Vertical Integration

Guideline 1 deals with vertical integration of a service-producing

19. There is some question as to whether there would be a new business at all, in view of the provisions of the guidelines to the effect that the principal factor in answering the question of whether there is a new business is the similarity of products. It is submitted that this would probably be considered as an expansion of the existing business due to the substantial similarity of conventional and synthetic crude.

20. The term new business is used in this section of the paper to include both new businesses established and small businesses acquired. 
business and Guideline 2 with the vertical integration of a goodsproducing business.

With respect to a service-producing business, the guidelines only permit backward vertical integration. A new or acquired business is related if the new business produces services used as inputs in or in furtherance of, or items of equipment or structure that become capitalized for the production, marketing and other activities of the established business. This is true provided that in the first two years after commencement of the new business, at least one-half of the annual output in terms of value would, under normal circumstances, ${ }^{21}$ be used in or for the established business. This guideline will not have much relevance in an oil context.

With respect to goods-producing businesses, the new business is related to the existing business if:

(i) the established business produces goods to be used as inputs in the production activity of the new business and, during the first two years, at least half of the current value of inputs in the new business are supplied by the established business; or

(ii) the new business produces goods, services, or items of equipment or structure to be used for the production and marketing or other activities of the established business, provided that in the first two years one-half of the output of the new business is used in the established business.

This guideline has some relevance to the examples cited earlier of the gas producer building a gas plant and the oil and gas producer establishing a chemical plant. If the producer in either case is building the plant for his own use and will supply $50 \%$ of the product to be processed by the plant, the plant will be related, but if he is not supplying that percentage of the input it would not be related. The same may apply to the service company example if $50 \%$ of the services of the existing business are used in the oil exploration: an unlikely event.

\section{(b) Substitutability of Products}

Under Guideline 3 a new business is related to an established business if the new business produces a product or services directly substitutable for an existing product or service being produced in Canada by the established business and, if during the first two years, at least one-half of the value would normally be used for the same types of commercial, public or personal end uses as the existing product. This guideline would apply with respect to the expansion from production of conventional to synthetic crude and thus such an expansion would be related.

\section{(c) Essentially the Same Technology and Production Processes}

This guideline is not of much relevance to the oil industry and will not be discussed any further than to say that if the technology and production processes are the same, the additional goods produced are produced by personnel with similar skills, and the new or acquired business is of such a magnitude that the established business remains a significant activity, the businesses are related.

21. The reference to normal is used to take into account special factors such as strikes or recessions that might cause an unexpected deviation. 


\section{(d) Result of Research and Development}

Guideline 5 would permit a company involved in research and development in Canada to use the fruits of that research and development without having to apply to the Agency for approval. This again has little relevance to the oil industry other than perhaps in the context of synthetic or heavy crude production where a new process is found.

\section{(e) Same Industrial Classification}

In order to analyze this guideline it is necessary to have a copy of the Standard Industrial Classification (S.I.C.) Manual published by Statistics Canada.22 Under Guideline 6 the new business is related to an established business if:

(i) both the new business and the established business are in the same business category and that category is in list 1 of the annex to the guidelines; and

(ii) the new or acquired business is, during its first two years of such a magnitude that the established business, as compared to the new business, remains a significant activity of the person.

There is an exception to (b) made for companies involved in the exploration and extraction of minerals. The exception is of course made to cover the situation where a mining exploration company discovers a mine and then puts it into production.

The guidelines outline two lists each containing a number of categories of business which have S.I.C. Classification numbers. In order to determine relatedness you find the category of the existing business, take the S.I.C. classification number or numbers applicable, and look at those numbers in the manual to see if the new activity is included in those categories. If they are both included in such category and the category is in list 1 , the business is related.

If the business in question is in list 2 to the annex to the guidelines, the S.I.C. classification is not appropriate for determining related businesses and you must establish this question otherwise. In other words, by being in list 2 , it does not mean that you are automatically unrelated, it just means that you must otherwise establish relatedness because the classification system is not appropriate for determining relatedness for such a business.

It will be observed that this is a purely mechanical process and accordingly may sometimes lead to inappropriate results. The guidelines suggest that in such circumstances one discusses with the Agency the question of whether businesses are related.

With respect to mineral exploration and extraction special rules are applied. The system distinguishes and separately classifies the activities of mineral exploration and mineral production. In the case of minerals the special classification operates as follows:

(a) oil and gas company builds a chemicals plant-not related-oil resources category is related to an established business in that category but unrelated to an established business in a different mineral resource category, i.e. a new or acquired metal mining business is related to an established metal mining business but unrelated to an established coal mining business;

22. An extract of that portion of this manual relating to the oil industry is attached to this paper as Appendix II. 
(b) an established metal mining business is deemed to be engaged also in the exploration for metals but only for metals;

(c) where a non-eligible person is engaged in mineral exploration but is not engaged in extraction, the exploration business is not deemed to be engaged in exploration for any particular mineral until such time as a mineral extraction business is established. Thereafter the person is deemed to be only in the exploration for the particular product which he is mining;

(d) a new coal mining business is considered unrelated to metal mining notwithstanding that the coal is discovered as a result of other mineral exploration.

This guideline would yield the following answers to the hypothetical fact situations cited earlier:

(a) oil and gas company builds a chemicals plant-not related-oil and gas production is category 064 while production of chemicals is category 365 or 378 ;

(b) oil field service company goes into oil exploration-not relatedoil and gas servicing is category 099 while oil and gas exploration and production is category 064;

(c) oil and gas company builds a gas plant-related-both gas plants and gas production are in category 064; This would seemingly be so regardless of whether one processes one's own or other people's gas. This is, of course, subject to the requirement that the established business remain a significant activity for two years.

(d) oil and gas company goes into a syncrude project-related-both synthetic and conventional crude are in category 064;

(e) oil and gas company goes into exploration for minerals or coalunrelated-oil and gas exploration is category 064 while coal mining is category 061 and metal mining is categories 051,052 , 058 and 059.

An oil and gas company engaged in mining exploration prior to the second proclamation can continue such exploration but once it is successful in developing, for example, a coal property, it is then restricted as regards mining activities to exploring for coal (or if it discovers metallic mineral to metallic minerals).

There are other ways in which the guidelines contemplate that relatedness can be established but these do not seem too germane to the oil industry.

All of the guidelines impose requirements with respect to the magnitude of the new business or use of the new products for a two-year period. Thereafter the related business can expand without restriction. Thus if one is willing to expand on a modest scale initially, the guidelines give considerable scope for expansion.

\section{DEALING WITH THE AGENCY}

The writer's experience has been that the Agency personnel are very approachable and helpful in determining applicability of the Act, although they sometimes take somewhat expansive views of the application of the Act. Those who have been involved in actual applications and have entered into the negotiating process will, I am 
sure, attest to the fact that you had best be prepared for a long process ${ }^{23}$ of hard bargaining with respect to what is of significant benefit to Canada. It has been the writer's experience that the Agency will attempt to extract every conceivable promise they can from an applicant. The promises they seek are not verbal, but must be contained in specified forms of undertakings which must be executed under seal of the company.

The basis on which the Agency was supposedly operating with respect to enforcement and obtaining undertakings was stated by Alistair Gillespie on June 5, 1973. At the time he stated that "In normal circumstances the inability to fulfill undertakings would lead to discussions with the Minister or perhaps the negotiations of new undertakings." He also expressed that the commitments were based on conjecture about the future and could not be guaranteed in their entirety. Recent newspaper reports indicated that the Agency is now insisting on more definitively worded undertakings and are studying better methods of enforcement. ${ }^{24}$ The problem of course in giving specific undertakings without retaining some protection for future dealings is that conditions change and an undertaking given at the time of acquisition may not be able to be lived with over its lifetime.

It should be borne in mind when giving undertakings, that failure to comply with them could possibly result in the government applying to the Court for an order rendering the investment nugatory. Under section 20 of the Act, a nugatory order is available, inter alia, where an investment is made on terms which vary materially from those disclosed in any notice in writing under section 8 and in other information given under the Act in relation thereto. Although it is not entirely clear that such wording would extend to an undertaking, the potential is there. In any event sections 21 and 22 make it clear that failure to comply with an undertaking may be contempt of court.

Experience I think has demonstrated that if a client is acquiring control of a Canadian business enterprise, he will have a much greater chance of success and encounter less problems in dealing with the Agency if he is buying a non-Canadian controlled company. This is particularly so in the resource industries, and the acquisition by a noneligible person of a Canadian controlled company or property leads to very difficult bargaining. It has been suggested that this was the reason for the rejection of the application of Sun Oil to acquire Sabre Petroleums Ltd.25

The Agency has a number of undertakings which are normally sought. These include:

(a) covenants to increase employment and if the applicant is working near or on an Indian reserve to employ native people;

(b) undertakings to drill wells or install facilities;

(c) covenants to use Canadian sourced goods, materials and services;

23. Although the Act in 8s. 10 and 13(1) contemplates that the review process would be completed in aixty days this has not worked out in practice. The Agency has the right under 8. 11(1) in effect to extend this time indefinitely. As previously indicated the average time for Part I applications is 117 days from certification. The Agency is apparently searching for ways to improve the time it takes to consider an application.

24. The Agency is sending out on the anniversary of the approval a questionnaire designed to determine if the undertakings have been met.

25. It is also one of the reasons for the refusal of the bid of Celanese Canada Ltd. to acquire control of Westmills Carpets Ltd. 
(d) covenants to increase participation by Canadians in share ownership and management and on the board of directors;

(e) reinvestment of earnings in Canada.

A commitment to sell stock to the public is an extremely difficult undertaking for a company to give and must, of necessity, be hedged upon such variables as market conditions, price, and the like. The Agency does not like this undertaking being phrased in such terms, making this an extremely difficult area of negotiation.

After an application is filed with the Agency, it is then forwarded to the provinces concerned. The Agency has claimed that, to a large extent, this requirement has been the cause of delay. The application is also forwarded internally to other federal government departments. It is suggested that if one is concerned with expediting an application, it is perhaps desirable to file the application concurrently with the appropriate provincial government official who, in Alberta, is Mr. A. G. McDonald, Deputy Minister of Business Development and Tourism, and advise the Agency that such has been done.

\section{CANADIANIZATION}

It is the writer's view that the most significant effect the Act has had to date is to encourage or force companies to Canadianize. It must be added, however, that they are doing so not for patriotic reasons but to avoid having to comply with the Act. Being considered Canadian for purposes of the Act is particularly important for oil companies as acquisitions must generally be made quickly or the opportunity will be lost. It is proposed in this portion of the paper to review some of the possible ways to Canadianize and thus comply with the Act by avoiding its application.

\section{Neutralizing Presumptive Sections}

It is often difficult to determine whether the Act applies to any particular company, especially public companies, as there are a number of presumptions created by the Act. ${ }^{26}$ For example, where a public company which has $25 \%$ (40\% in the case of private companies) or more of the voting rights ordinarily exercisable at shareholders' meetings owned by one or more non-eligible persons the company is, unless the contrary is established, presumed to be a non-eligible person. In addition, the Act presumes that where $5 \%$ or more of the shares are owned by any one non-eligible person, the company is a non-eligible person. These are both obviously low thresholds, and it is very easy for a company to be presumed non-eligible. The question which arises is how to rebut the presumption. The easiest and most unusual way to rebut the presumption is to point to other Canadian shareholders who have larger holdings. The desire to neutralize the $5 \%$ presumption is, it is understood, one of the reasons for the recent share exchange made between Dome Petroleum Limited and Dome Mines Limited. Dome Mines owns approximately $23 \%$ of Dome Petroleum and this is the controlling interest. Thus Dome Petroleum's status under the Act is determined by the share status of Dome Mines which is widely spread, with no shareholders holding in excess of $5 \%$ and only approximately $29 \%$ of the shareholders of Dome Mines having addresses in Canada. Dome Mines 
obviously feels that in view of their widespread shareholdings no shareholder or group of shareholders controls the company and thus the board of directors is deemed by the Act to control it. ${ }^{27}$ It is understood that Dome Mines was fearful that if a non-eligible person acquired more than $5 \%$ of its shares the presumption would apply and the company would not be able to rebut it. In order to counteract this Dome Petroleum Limited and Dome Mines Limited entered into a share exchange whereby Dome Petroleum issued 700,000 shares in exchange for 600,000 shares $(9.3 \%)$ of Dome Mines. Thus Dome Petroleum will hold a sufficiently large block of Dome Mines so as to be able to rebut the $5 \%$ presumption. Both companies were also concurrently increasing the Canadian content of their boards of directors. It will be interesting to see if they will now be successful in getting the section 4(1) ruling which has previously not been given.

In order to avoid becoming a non-eligible person it is possible for a company to introduce share transfer restrictions which restrict transfers to non-Canadians to certain levels. The Canada Corporations Act has for some time permitted constrained share companies who have such transfer restrictions. It was recently reported ${ }^{28}$ that Brascan Limited was seeking an amendment to its by-laws which would ensure that $51 \%$ of its shares would at all times be held in Canada and would also prevent more than $10 \%$ being held by an individual or company outside Canada. This is clearly possible for a private company but public companies may have problems with the securities commissions or stock exchanges.

\section{Becoming Landed Immigrants or Canadian Citizens}

Another, and probably the most obvious method of Canadianization, is for the controller of the Canadian business enterprise to become a landed immigrant or a Canadian citizen. This may have serious tax consequences and may otherwise be objectionable, particularly in view of the increasing spectre of government controls which exist in Canada.

\section{Disposition of Control}

An additional method which can be used to Canadianize a company is to have the non-eligible person dispose of his control. There are many ways to accomplish this, including sale of shares, reorganization of share structure, and use of voting trusts.

The surest method to successfully accomplish a disposition of control is to have the non-eligible controller dispose of his shares to Canadian citizens or Canadian controlled companies. This is essentially what Western Decalta Petroleum Ltd. proposed. That company is controlled by Hudson's Bay Mining and Smelting Ltd., a company which is controlled by non-eligible persons. A proposal was made whereby Hudson's Bay Mining would dispose of its shares and debentures in Western Decalta to a subsidiary of Brascan Ltd., a Canadian controlled company. This also appears to have been the method employed by Slater Walker of Canada Limited. Slater Walker of Canada Limited was controlled by Slater Walker Securities of London and certain affiliates who together owned 49.9\% of the shares of Slater Walker of Canada Limited, with the balance being held by Canadian interests. The Canadianization was effected by virtue of a number of transactions which left Slater Walker

27. S. $3(7)(b)$.

28. Globe and Mail Report on Business, May 7, 1976, p. 1. 
of Canada holding $49.9 \%$ of its own shares through a newly-acquired subsidiary, Toronto \& London Investment Company Ltd. The first step involved Toronto \& London Investment Company Ltd. acquiring $49.9 \%$ of Slater Walker of Canada's shares from the U.K. parent and its affiliates. The next step involved Slater Walker of Canada acquiring over $99 \%$ of the outstanding shares of Toronto \& London. In the end result, Toronto \& London was a wholly-owned subsidiary of the Slater Walker of Canada, yet controlled Slater Walker of Canada through its 49.9\% shareholding of such company.

In jurisdictions where it is permissible for a corporation to acquire its own shares the company could repurchase all or a sufficient number of the shares of a non-eligible person to become Canadianized.

Another scheme which would appear workable is to have the foreign controllers convert their controlling shares into a class of shares which is non-voting. ${ }^{29}$ This can be done either by an arrangement under the Companies Act or by a reorganization of capital. The rights which can attach to such new shares are unlimited but will undoubtedly include prior rights on liquidation and priority in participation and dividends. The shares however, would clearly have to be non-voting in all circumstances, as the usual provision that preference shares become voting after certain arrears of dividends is not desirable in that it may result in the company again becoming non-eligible at the same time the preferred shares become voting. It is doubtful, however, that the shares becoming voting in such an event would constitute a reviewable acquisition transaction. Care must be taken in setting the share conditions to ensure that the class created does not in fact control the company by virtue, for example, of being able to require redemption of the shares.

\section{Voting Trusts}

An additional method which has been explored for purposes of Canadianization is to have the non-eligible person transfer the voting rights of his shares to resident Canadians, while retaining other attributes of share ownership. The Agency has taken the position that this will not Canadianize the company. The main publicized example of this, and the one which elicited a response of the Foreign Investment Review Agency was Bovis Corporation's attempt to Canadianize by this method. In this case the Canadian company was $61 \%$ owned by an English company. The English company purported to give the voting rights on their $61 \%$ to three of the corporation's non-management directors. The right to vote was stated to be irrevocable for five years, and at the end of such time could be revoked only with the combined approval of such three Canadian directors and the parent company. The Agency made a statement at the time to the following effect: ${ }^{30}$

... the transfer of voting rights by non-Canadians, without the corresponding transfer of equity ownership, is not by itself sufficient to change the ultimate control of the corporation-this is patently 80 in cases where the voting rights may revert to nonCanadians at some time in the future-such stripping away of one of the properties of a common share just does not achieve what the companies would like to do ... retention of beneficial ownership of equity by foreign parents is sufficient to bring the Canadian company within the scope of the review requirements.

29. The writer understands that this was done in the Sulpetro of Canada Ltd. reorganization. 30. The Globe and Mail, Nov. 30, 1974. 
This argument may be sustainable in view that the Act refers to control in fact. Another interesting sidelight to this method is that the revocation of the voting rights agreement would be a reviewable transaction under the Act by virtue of section $3(6)(c)$.

\section{TITLE PROBLEMS AND CONSIDERATIONS}

One of the side effects which the Act has is to create a cloud on title to property which has passed through the hands of a non-eligible person without the requisite approval of the Agency. Section 20(1) of the Act provides that where a non-eligible person or a group has made an investment without complying with the Act, or after receiving approval has proceeded on a basis different than that subject to the approval, a Superior Court may make such order as in its opinion is required in the circumstances. To this end the investment shall be rendered nugatory not later than the expiry of such period of time as the court considers necessary in order to allow, avoid, or reduce to the extent possible any undue hardship to any person who was not involved in the investment knowing that it was subject to be rendered nugatory under the Act. The court is given broad authority including power to direct the revocation, suspension or control of voting rights or to direct disposition by the person of the shares or property improperly acquired. The Act contains no time limit within which this power can be exercised, and it conceivably could happen after subsequent transfers of the property have taken place. Such being the case, it is possible that a cloud on a title continues to exist even after a non-eligible person who has improperly acquired property has disposed of it. Trying to determine whether any person who has owned property is a non-eligible person and whether he acquired the requisite approval is difficult and, as previously discussed, would involve making sure that the owner of the property lived up to any undertaking he gave the Agency at the time of the acquisition.

What exactly the word "nugatory" means is open to question, although the Senior Legal Advisors to the Agency have repeatedly taken the point of view that the powers of the section do not extend to requiring the vendor to refund the money. In other words, they feel the only power of the court is to deal with the purchaser and order him to dispose of the property. Whether they are right in this view is questionable as the Shorter Oxford Dictionary defines "nugatory" as "of no force, invalid, useless, futile, inoperative". An American ${ }^{31}$ case dealing with the word as it appears in a judgment held, after examining dictionary meanings, that it had the same meaning as void.

In view of the Agency's interpretation the real meaning from the point of view of the vendor may not be too important. The Act does not contain any procedure whereby the title cloud can be rectified as only the non-eligible acquiror has a right under the Act to apply for review, and once he has disposed of the property, the persons who have subsequently acquired, must bear any risk involved.

The writer is not aware of any law firms varying their title procedures to deal with this problem so it may be judged of minor importance. 


\section{COUNSEL'S DUTY ON PURCHASE AND SALE OF A CANADIAN BUSINESS ENTERPRISE}

\section{Vendor's Counsel}

The obligation to comply with the Act is placed on the purchaser but this does not mean that the vendor can or should ignore the Act. As previously discussed, the court has power to render an investment nugatory and in so doing section 20(2) provides it cannot direct the doing of any Act by a person who was not involved in the investment knowing, or in circumstances where he ought reasonably to have known, that it was subject to being rendered nugatory. Accordingly, if a vendor is to escape the consequences of a section 20 order, he must prove he did not know and ought not reasonably to have known that the purchaser did not comply with the Act when he should have. Therefore, the vendor should receive appropriate assurances that the purchaser is not a noneligible person. This assurance could take the form of a representation and warranty, coupled with an indemnity in the event it is false or, alternatively, take the form of counsel's opinion to be delivered as a condition of closing. The importance of taking reasonable steps to ensure the Act is complied with, is particularly important where the vendor takes security on the assets sold, as he then has much more to risk by a nugatory order.

Anytime a non-eligible person is making an acquisition, counsel for the vendor should ensure that the agreements specifically state (as contemplated by section $3(6)(c)$ of the Act) that it is conditional upon receipt of approval of the Agency. The vendor should also obtain covenants from the purchaser to prosecute the application diligently and continuously. It is desirable to provide a monetary incentive (such as interest or front money) for the purchaser to push the application and also to provide an outside date on which the vendor can terminate the transaction. In order to police the covenant to pursue the application it is necessary to have covenants that the purchaser will keep the vendor advised as to progress of the application, and will supply the vendor with all communications in respect of the application. From the point of view of the vendor it is desirable to have the purchaser agree with the vendor that he will give certain minimum undertakings to the Agency. This is designed to protect the purchaser from the vendor deciding later he does not really want the property and being able to effectively get out by refusing to give undertakings to the Agency. Needless to say there will be some tough bargaining required for a vendor to succeed in getting the foregoing covenants and assurances in an agreement.

The vendor is also usually called on to give warranties as to title and the absence of liens or claims against the property; thus counsel for the vendor should consider the title problems raised by section 20 and discussed earlier.

\section{Purchaser's Counsel}

From the point of view of counsel to a non-eligible purchaser, it is necessary to ensure the obligation to buy is conditional on approval or deemed approval under the Act and also to obtain undertakings from the vendor that he will assist the purchaser in filing his application and will supply all required information with respect to its business in order to expedite the application. It is also desirable to obtain from the purchaser what, if any, undertakings the purchaser will give to the Agency. 
Vendor's undertakings often can play a fairly decisive role in determining whether the acquisition is for the significant benefit of Canada, particularly in marginal circumstances where there is not much else to offer other than that the proceeds of sale will be used in a certain specified manner in Canada.

\section{CONCLUSION}

In the period since the Act was introduced a number of problems affecting its application to the oil industry have been resolved or reduced but a large number of problem areas still exist. The Minister has announced that he is launching a review of Part I of the Act with particular emphasis on making public more information with respect to decisions and ways of speeding up the application process. It is hoped that the oil industry will let their concerns be known so that they can be considered in such a review.

\section{APPENDIX I}

\section{LIST OF CERTAIN MATERIALS AND ARTICLES RELATING TO} THE FOREIGN INVESTMENT REVIEW ACT

1. Foreign Direct Investment in Canada (the Gray Report).

2. News Release by Minister of Industry, Trade and Commerce dated $\mathrm{Jan} .24,1973$ and issued contemporaneously with the introduction of the proposed legislation in the House of Commons.

3. Minutes of Proceedings and Evidence of the House of Commons Standing Committee on Finance, Trade and Economic Affairs with respect to the Foreign Investment Review Act (Bill C-132)-vol. I, issues numbered 26, 27, 38, 39, 40, 41 and 42 are particularly helpful because they contain the evidence given to the Committee by the Minister, Mr. Gillespie, and his officials with respect to their views on the legislation and its interpretation.

4. Formal Briefs received by the House of Commons Standing Committee on Finance, Trade and Economic Affairs with respect to the Foreign Investment Review Act (Bill C-132)-vol. II-Issue No. 42. Submissions by the Toronto Stock Exchange, Investment Dealers Association and the Canadian Bar Association are comprehensive and there are other submissions which focus upon the interests and effects of the legislation upon certain sectors such as real estate, merchant banking and manufacturing.

5. Donaldson and Jackson, Foreign Investment Review Act-An Analysis of the Legislation, (1975) 53 Can. Bar Rev. 191.

6. Foreign Investment Review Act-Phase I by Warren Grovercontained in the first issue of the Journal of Canadian Business Law (Canada Law Book).

7. Foreign Investment Review Act-Cassette-Law Society Department of Continuing Education-(Allen Karp, Joel Bell, Warren Grover, Herbert Abramson).

8. Glover, Canada's Foreign Investment Review Act, Bus. Law, vol. 29, April, 1974.

9. McMillan, After the Gray Report: The Tortuous Evolution of Foreign Investment Policy, McGill L.J., July, 1974. 
10. Crookwell and Wrigley, Canada's Response to Multinational Enterprise, The Bus. Q., Spring Issue, 1975.

11. Arnett, Canadian Regulation of Foreign Investment: The Legal Parameters, Can. Bar Rev., vol. 50, 1972.

12. Stikeman, Foreign Investment Review Act-The Shape of Things to Come (published by Richard De Boo Limited).

13. Canadian Foreign Investment Review Seminar-held April 30, 1974 (published by Richard De Boo Limited).

14. Tax and Other Problems Across the U.S.-Canada Border-Section 13-Canadian Non-Tax Considerations by James C. BailliePractising Law Institute Seminar-April/May, 1974-Course Handbook Series (No. 71) at 418-422 and 451-465.

15. Stikeman, Foreign Investment Review: Canada's New Medicine, The Bus. Q., Autumn Issue, 1974.

16. Foreign Investment in Canada (a loose leaf service published by Prentice-Hall of Canada Ltd.), edited by Peter R. Hayden and Jeffrey H. Burns.

17. Langford, Canadian Foreign Investment Controls (published by CCH Canadian Limited).

18. Dominion Companies Law Reporter-Tab Division "Foreign Investment Controls"-(a loose leaf service published by $\mathrm{CCH}$ Canada Limited).

19. Spoliansky and Easton, Beware of Canadian Subsidiaries, Bus. Law., vol. 30, July, 1975.

20. Bonney, Foreign Investment Review Act, (1975) 13 Alta. L. Rev. 83.

21. Richardson and Quigley, The Resource Industry, Foreign Ownership and Constitutional Methods of Control, (1975) 39 Sask. L. Rev. 92.

22. Hayden and Burns, The Foreign Investment Review Act, (1975) 9 Gazette 144.

23. Byleveld, Foreign Investment Review Act: Now Fully Hatched, (1975) Can. Bank 25.

24. The Foreign Investment Review Act, edited proceeding of program held in May, 1975) (published by Law Society of Upper Canada).

25. Foreign Investment Review Act by Graeme C. Hughes, (1975) (published by Carswell Company).

\section{APPENDIX II}

\section{EXTRACT FROM STANDARD INDUSTRIAL CLASSIFICATION MANUAL}

\section{DESCRIPTIONS OF CLASSIFICATIONS}

\section{DIVISION 4-MINES (INCLUDING MILLING), QUARRIES AND OIL WELLS}

\footnotetext{
Major Group 1-Metal Mines

051 Placer Gold Mines.Establishments primarily engaged in mining gold by placer or hydraulic methods. This industry also includes the dressing and beneficiating of the
}

ore and the production of bullion at the site of the mine.

052 Gold Quartz Mines.Establishments primarily engaged in operating lode mines for gold. This industry also includes the dressing 
and beneficiating of the ore and the production of bullion at the site of the mine.

$057 \quad$ Uranium

Mines.Establishments primarily engaged in mining uranium or radium ores and in dressing and beneficiating such ores.

058 Iron Mines.-Establishments primarily engaged in mining iron ore and in dressing and beneficiating such ores.

059 Miscellaneous Metal Mines.Establishments primarily engaged in mining metal ores not elsewhere classified and in dressing and beneficiating such ores. The following types of mines are included in this industry: silver, copper-gold-silver, nickel-copper, silver-cobalt, silver-leadzinc, molybdenite, manganese, mercury, tungsten, titanium, cerium, rare earths, columbium, tantalum, antimony, magnesium and beryllium.

Major Group 2-Mineral Fuels

061 Coal Mines.-Establishments primarily engaged in mining coal, whether anthracite, bituminous or lignite. This industry includes establishments which break, wash, grade or otherwise prepare coal for use as a fuel, whether operated by a coal-mining enterprise or on a contract basis.

Crude Petroleum and Natural Gas Industry.-Establishments primarily engaged in the production of petroleum or natural gas wells or from surface shales or sands. Establishments primarily engaged in recovery of the naphtha content of natural gas are also included. The products of these establishments are pentane and heavier liquids, liquified petroleum gases such as butane, propane and butane-propane $\mathrm{mix}$ tures. In some cases elemental sulphur is recovered as a by-product. Establishments primarily engaged in manufacturing coal gas, when not combined with a blast furnace or chemical plant, are classified in Industry No. 369-Miscellaneous Petroleum and Coal Products Industries; while establishments primarily engaged in distributing manufactured or natural gas to consumers through a system of mains are classified in Industry No. 574-Gas Distribution.
Major Group 3-Non-Metal Mines (except Coal Mines)

071 Asbestos Mines.Establishments primarily engaged in mining and milling asbestos fibre.

072 Peat Excavation.Establishments primarily engaged in recovering and processing peat.

073 Gypsum Mines.-Establishments primarily engaged in mining gypsum. Establishments primarily engaged in manufacturing gypsum products which also mine gypsum, are classified in Industry No. 359Miscellaneous Non-Metallic Mineral Products Industries.

079 Miscellaneous Non-Metal Mines.-Establishments primarily engaged in mining and milling nonmetallic minerals not elsewhere classified. This industry includes mines such as the following: soapstone and talc, barite, diatomite, mica, ochre and iron oxide, feldspar, nepheline syenite, quartz, silica, fluorspar, salt, potash, sodium sulphate, lithia, magnesite, brucite, gem stones, pumice, volcanic dust, whiting, pozzolana, kyanite, natro-alunite, sodium carbonate, magnesium sulphate, actinolite, serpentine, stronium, graphite, phosphate, pyrite.

Major Group 4-Quarries and Sand Pits

083 Stone Quarries.Establishments primarily engaged in quarrying and crushing igneous rocks (such as granite) or sedimentary rocks (such as limestone, marble, shale, slate and sandstone). Establishments primarily engaged in cutting, shaping or finishing stone are included in Industry No. 353-Stone Products Manufacturers.

087 Sand Pits or Quarries.Establishments primarily engaged in the extraction, crushing and screening of sand and gravel from pits or quarries.

Major Group 5-Services Incidental to Mining

096 Contract Drilling for Petroleum.-Establishments

primarily engaged in contract drilling of wells for petroleum or gas. This industry includes contractors that specialize in "spudding in" or "drilling in" and in building, repairing and dismantling rigs and derricks. 
098 Other Contract Drilling.Establishments primarily engaged in contract diamond drilling.

099 Miscellaneous Services Incidental to Mining.Establishments primarily engaged in providing services necessary to the operation of petroleum and gas fields, such as running, cutting and pulling casings, tubes and rods; cementing wells; shooting wells; perforating well casings; acidizing and chemically treating wells; cleaning out, bailing, and swabbing wells; and drilling water intake wells. This industry also includes establishments primarily engaged in providing services incidental to the operation of metal and nonmetal mining, such as mine exploration and development work including the removal of overburden and the sinking of shafts. Old style prospecting is classified here, but geophysical surveys, gravimetric surveys and seismographic surveys are in Industry No. 864-Engineering and Scientific Services.

\section{DETAILS OF CLASSIFICATIONS}

\section{MINES (INCLUDING MILLING), QUARRIES AND OIL WELLS}

\section{METAL MINES}

051 Placer Gold Mines

Gold bullion production at placer gold mine

Gold mine, alluvial

Gold mine, hydraulic

Gold mine, placer

Hydraulic mine, gold

Placer mine, gold

052 Gold Quartz Mines

Gold bullion production at lode mine

Gold mine, lode

Gold quartz mine

Lode mine, gold

\section{Uranium Mines}

Mining radium and uranium

Pitchblende mine

Radium bearing ore milling

Radium mine

Uranium mine

Uranium ore milling

058 Iron Mines

Hematite mining

Iron mine

Iron ore milling

Iron pellets, $\mathrm{mfg}$.

Magnetite mining

Magnoferrite mining

Manganiferous iron ore mining

Mining iron

Pyrrhotite mining

059 Miscellaneous Metal Mines

Antimony mine

Beryllium mine

Cerium mine

Chalcopyrite ore mining

Chromite mine

Chromite ore milling

Cinnabar mine
Cobalt mine

Cobalt ore dressing and beneficiating

Cobalt ore milling

Columbium mine

Copper mine

Copper ore dressing and beneficiating

Copper ore milling

Copper-gold-silver mine

Copper-gold-zinc mine

Copper-zinc mine

Cuprite ore mining

Galena ore mining

Lead mining

Lead ore mining

Lead-zinc mining

Lead-zinc ore milling

Magnesium mine

Manganese mine

Mercury mine

Molybdenite mine

Nickel mine

Nickel ore dressing and

beneficiating

Nickel ore milling

Nickel-copper mine

Quicksilver mine

Rare earths mine

Scheelite ore mine

Silver mine

Silver ore milling

Silver-cobalt mine

Silver-lead mine

Silver-lead-zinc mine

Sphalerite ore mining

Tantalum mine

Titanium mine

Tungsten mine

Tungsten ore dressing and beneficiating

Vanadium mine

Wolframite mine

Zinc and lead mine 
Zinc blend ore mining

Zinc mining

\section{MINERAL FUELS}

\section{Coal Mines}

Anthracite mine

Bituminous coal mine

Bituminous coal screening plants

Breaking, washing, grading coal (contract)

Coal and lignite mine

Coal breaking, washing, grading (contract)

Colliery

Lignite and coal mine

Lignite mine

Semi-anthracite mine

Sub-bituminous coal mine

064 Crude Petroleum and Natural Gas Industry

Bituminous sand and oil shale digging

Bituminous sand mining for oil extraction

Combustion chamber natural gas processing plant

Crude oil production

Crude petroleum production

Helium content from natural gas, recovery of

Liquefied petroleum gases from natural gas, production

Liquid gas plant (from natural gas)

Mining oil shale, digging

Naphtha content from natural gas, recovery of

Natural gas absorption plant

Natural gas cleaning plant

Natural gas from oil shale or sand

Natural gas well

Natural gasoline plant

Oil sand mining

Oil shale mining

Oil shale or bituminous sand digging

Oil well

Petroleum, from shales or sand, production

Petroleum well

Sulphur, extraction from natural gas

Tar sand mining

Well drilling, petroleum (oil company)

\section{NON-METAL MINES EXCEPT} COAL MINES

071 Asbestos Mines

Asbestos fibre, milling

Asbestos mine
072 Peat Extraction

Peat bog

Peat cutting

Peat digging

Peat moss digging or harvesting

073 Gypsum Mines

Gypsum mine

Plaster mine, pit or quarry

079 Miscellaneous Non-Metal Mines

Actinolite mine

Asphalt, natural, mine

Barite mine

Black lead mine

Brine well

Brucite mine

Chalk mine or quarry

Coloured earth mine

Corundum quarry

Diatomaceous earth mine

Diatomite mine

Dolomite mine or quarry

Epsom salts lake

Epsomite lake

Feldspar mine

Fluorspar mine

Fuller's earth mine

Ganister mine

Garnet mine

Gem stone mine

Graphite mine

Grinding pebble pit or quarry

Grindstone mine or quarry

Iron oxide mine

Jade mine

Kyanite mine

Lithia mine

Lithium minerals mine

Magnesitic dolomite mine

Magnesium sulphate mine

Mica mine

Natro-alunite quarry

Natural abrasives mine

Nepheline syenite mine

Ochre mine or quarry

Packers' salt, mfg.

Perlite mine

Phosphate rock mine

Plumbago mine

Potash mine

Pozzolana mine

Processing of salt

Pulpstone quarry

Pumice quarry

Pyrites mine

Pyrophyllite mine

Quartz mine

Quartzite mine

Refining salt

Rock salt mine

Rock salt processing

Salt cake lake

Salt mine

Salt processing 
Salt refining

Serpentine mining

Silica mine

Soapstone mine

Soda ash lake

Sodium carbonate lake

Sodium sulphate lake

Stronium minerals quarry

Talc mine

Vermiculite mine

Volcanic ash quarry

Whetstone quarry

Whiting mine

\section{QUARRIES AND SAND PITS}

083 Stone Quarries

Basalt mine, pit or quarry

Conglomerate mine or quarry

Granite quarry

Igneous rock quarry

Limestone quarry

Marble quarry

Marl bed or pit

Sandstone quarry

Sedimentary rock quarry

Shale quarry

Slate quarry

Stone crushing quarry

Stone mine, pit or quarry

Traprock mine or quarry

087 Sand Pits or Quarries

Gravel and sand grinding and screening

Gravel pit or quarry

Sand and/or gravel pit

Sand pit or quarry

\section{SERVICES INCIDENTAL} TO MINING

096 Contract Drilling for Petroleum Contract drilling for petroleum Contract drilling, oil or gas well
Drilling gas wells, on contract basis

Natural gas well drilling, contract

Oil field construction

Oil well drilling, contract

Well sinking and drilling, oil, contract

098 Other Contract Drilling

Contract diamond drilling

Diamond drilling

099 Miscellaneous Services

Incidental to Mining

Acidizing oil wells, contract

Acidizing wells-oil field

Bailing wells-oil field

Cementing wells-oil field

Chemically treating wells-oil

field

Cleaning out wells-oil field

Cutting casings, tubes and rodsoil field

Drilling water intake wells-oil field

Gas-oil ratio testing

Logging oil wells

Mine development work

Mine exploration

Mining services, n.e.s.

Oil well servicing

Perforating well casings-oil field

Prospecting, ex. geophysical, gravimetric and seismographic surveys

Pulling casings, tubes and rodsoil field

Removal of overburden-mining

Running casings, tubes and rods-oil field

Shaft sinking (mining)

Shooting wells-oil field

Sinking of shafts

Swabbing wells-oil field

Treating wells-oil field

Water intake well drilling-oil field 